\title{
LIBRARY ASSOCIATION
}

\author{
ANNUAL MEETING
}

$I^{\mathrm{N}}$ $\mathrm{N}$ his presidential address to the Library AssociaI tion on September 28, Mr. C. B. Oldman, principal keeper in the Department of Printed Books, British Museum, considered three or four general questions relating to the keeping of books. Are libraries, as at present organized, doing all that they should to ensure the preservation of recorded knowledge, as well as facilitating its dissemination ? Is the emphasis to-day too much on the supply of day-to-day requirements, including specialized information for the research worker? Is the general, comprehensive library already outmoded, or should there continue to be at least one library aiming, as (in theory, at any rate) the British Museum Library at present does, at acquiring everything and keeping everything that it acquires?

These are obviously questions bearing closely on the proposals for library reorganization that are implicit in the project for a Science Centre, and, although not limiting them specifically to science and technology, Mr. Oldman's remarks in the final section of his survey were concerned especially with the general research library, of which the British Museum is the acknowledged chief. Referring briefly to the functions of the specialist libraries, in stressing the importance of such libraries being able always to supply their users with the latest information, he perhaps overstressed the extent to which this permits such libraries to discard freely what was once important. Nevertheless, he correctly indicated the inadequacy of most such libraries for historical purposes, even in the field in which they specialize, and in pointing out that the term 'research' is often misapplied, for example, to hunting for information, he reminded his audience that science has no monopoly of research, if one defines research as original investigation involving the search for untapped or hitherto imperfectly appreciated sources and the drawing of new conclusions from what is found.

The discussion of the function of research libraries has so far not been very conclusive, and Mr. Oldman, in pointing out that what distinguishes the great research libraries is the large proportion of research material they contain, remarked that their strength derives from the extent as much as from the character or quality of their accumulations, and this is the root of the problem confronting them. If the great research libraries of the world continue to grow as they have in the past half-century, and if, while retaining all that has been already acquired, they are to endeavour to meet the new demands that are constantly being made upon them, with the multiplication of faculties and the springing up of new fields of study, they must face a prospect of infinite expansion, with all the problems of accommodation, staffing and finance involved. In the United States, in particular, they are beginning to wonder whether they will not be forced to call a halt. Mr. Fremont Ryder in 1944 estimated that, on an average, the American university library is doubling its stock every sixteen years, and in different degrees the same problem faces the whole group of general research libraries. So far as the British Museum is concerned, within a few years the present policy will lead to saturation point, and a new library on a new site will be required. Nevertheless, Mr. Oldman thought that completeness should remain the target and, when it is no longer possible to pursue the present policy, he suggested that it would be better to create separate subject libraries which will remain constituent parts of the one national library rather than to reduce current holdings or future intake. Such problems clearly demand close consideration in formulating plans for a national reference library for science and technology.

Several other papers presented at the conference were also of general interest to the scientific worker. Two papers read on September 30, for example, dealt with standards of service and the individual library and its place in the national system. In the first of these, Mr. J. H. Haiste, of Rugby, dealt with the question of standards and co-operation generally from the point of view of the library of the smallish authority, representing about a quarter of all library authorities in Great Britain. Mr. Haiste insisted that the service provided by such a library must be in harmony with the community it serves, but on the highest possible level for that community, and he thought that failure to adjust service to the conditions and needs of the community is mainly responsible for the failure of the library service in Britain to achieve its proper status. While fully recognizing the difficulties and disadvantages of the smaller library, Mr. Haiste thought that it should be less docile about its limitations: a cleaner, clearer scheme of co-operation would make for better standards of service, but the energy is derived from the individual libraries in each region able to do their own communal jobs first, and willing also to accept responsibility for providing on their own shelves a strong subject representation for the general benefit. He agreed with the Vollans's report that the most effective contribution the individual library can make to the success of library co-operation is to improve its own bookstock and its services to its own readers.

The second paper, by Mr. A. H. Chaplin, deputy keeper in the Department of Printed Books, British Museum, was concerned with the place and function of the British Museum. Describing the position of fundamental importance which the Museum occupies in building up a comprehensive national stock of books and the way in which the policy already indicated by Mr. Oldman is implemented, Mr. Chaplin, before he went on to consider the important contribution made by the Museum to the complete national bibliography, noted some classes of printed matter of potential historical interest which, although technically 'published', often failed to reach the Museum. There is, however, also need for a centre for co-operative work in supplementing the information contained in the original "Short Title Catalogue" of English books printed down to 1640, in Wing's list of English books published between 1640 and 1700 and in such lists as the "English Catalogue", relating to the nineteenth and twentieth centuries. Mr. Chaplin believes that the resources of the Museum and of a number of other important libraries could be both more economically and more effectively used if there were close co-ordination between them in their purchases of foreign books. The British Museum does not to-day attempt to cover systematically certain kinds of foreign publications, particularly 
scientific and technical literature, but there is no certainty that the publications not taken by the British Museum will be found in some other British library, still less that, if acquired, they will be preserved. He suggested that the consultation and co-operation in this field already begun between the British Museum and other government libraries should be extended to the various national and university libraries and put on a systematic basis. Each library, while continuing to acquire the publications likely to be called for by its own readers, would undertake responsibility for acquiring, in particular fields to be allotted to it, the publications which, because of their obscurity or very restricted interest, are at present neglected. The British Museum, apart from developing more thoroughly its collections in the fields where it is already particularly strong, would acquire the books to which no one else is prepared to give house-room and would store those which every other library would prefer to discard. A natural corollary of such a system of co-ordination would be the making of a union catalogue of all the books to which it applies, giving at least one location for each book. In conclusion, Mr. Chaplin indicated the willingness of the Museum authorities, as part of any such projects, to make, after wide consultation, such changes in Museum practices as would bring them into harmony with the majority of co-operating libraries and remove present obstructions. Any such scheme, however, would require greatly increased resources in staff, in money and in buildings, and they will only be forthcoming if these demands are presented to Parliament backed effectively by influential opinion.

The place of the non-public library in the library system was considered by Mr. E. A. Baker, librarian in the Ministry of Food, in a paper also read on September 30. Stressing the need for greater cooperation between all types of libraries, Mr. Baker suggested that each public library participating in one of the subject specialization schemes recently set up in some of the regional bureaux should be able to look to a specialist library in its particular field for assistance in book selection and bibliographical information. He also suggested that the time has come for a thorough investigation into the constitution and organization of the Library Association with special reference to the representation of the non-public libraries.

Mr. W. B. Paton's paper on "Standards of Library Staff : Recruitment and Training", read on September 29, stressed the dependence for success of a library service on the quality of its staff. The general education of librarians should, he maintained, reach the standard at present demanded by the Library Association from examination candidates, and for preference should surpass it. This could be possible if the same rigid standards were not applied to the non-professional categories whose service is likely to be temporary. He also thought the division of staffs into professional and non-professional categories should become the declared policy of the Library Association as soon as possible, that university graduates should be welcomed as recruits to the library service and that in time this would be a normal standard of entrance. He urged that the time has come for the Library Association to reconsider its examination syllabus to relate it more closely to the needs of special libraries. He also suggested that the conduct of the examinations should be integrated with the activities of the schools of librarianship. The number of these schools should be reduced, but the qualifications of their teaching staffs should be raised and opportunity sought to link the schools with universities. A personal interpretation. of the office of librarian, given by Mr. F. Raymond Smith, librarian of the Guildhall, on Soptember 28, also stressed the importance of the professional ideal and discussed the closer adjustment of professional training to the needs of special libraries, and the related issues of the common structure and functions of both special and municipal libraries and librarians. On Oetober 1, Mr. Bengt Hjelmqvist, head of the Library Board in Sweden, described the operation of public libraries in Sweden under fifty years of State aid.

\section{FIFTH INTERNATIONAL SPECTROSCOPY COLLOQUIUM}

7 HE fifth International Spectroscopy Colloquium, organized by Prof. F. X. Mayer, chairman of the Spectrochemistry and Colorimotry Group of the Austrian Society of Chemists, was held at Gmunden, Salzkammergut, Upper Austria, during August 30September 3. More than five hundred members attended, representing twenty-three countries, and the importance to practical spectroscopy of these international gatherings is shown by the significant increase in the number of participants on each successive occasion. Two days were allotted to each of the principal sections-emission spectroscopy and molecular spectroscopy-with a mid-week excursion to the Nitrogen Works and Steel Works at Linz. The meetings were held at the Town Theatre, while a one-day symposium on direct-reading spectroscopy was held concurrently at the Kurhotel.

Emission spectroscopy. Three papers dealt with the analysis of silicates and silicate rocks and similar materials, for which various types of arc excitation are used. Progress in the detection of sulphur and halogens by high-current, low-voltage, short-duration spark discharges was reported, followed by studies of arcs and sparks in different atmospheres, highly reproducible 'sparking-off' phenomena and the stroboscopic examination of controlled sparks. A new atomizer using electrostatic spraying for flame analysis was described, and the use of amyl alcohol has been found to give a three-fold increase in accuracy and sensitivity in detecting calcium and magnesium.

Further studies of the Standard Paper Density Scale were discussed; improved results have been obtained with scale lines having a profile similar to that of spectrum lines. In determining the absolute error of photometric measurements, the use of polarization prisms is least open to objection, provided that the prisms are in perfect condition. Other subjects included errors in the 'method of additions', calibration with the rotating step-sector and devices for producing linear calibration graphs. Advances in equipment concerned microphotometers (one incorporating a recording electro-dynamic oscillograph, and the other an electric comptometer with a printing dovice), stigmatic grating spectrographs, and a plane grating in convergent light for the study of hyperfine structure and isotope shifts.

Direct-reading spectroscopy. A now universal quantometer and two British designs of the polychromator type (a grating instrument and an attach. ment to a quartz instrument) were described. Other 